\title{
Silicate fertilization in non-conventional vegetables in the southern region of Minas Gerais in Brazil ${ }^{1}$
}

\author{
Luis Cláudio Pessoa Oliveira², Douglas Correa de Souza²* (D), Luis Felipe Lima e Silva ${ }^{4}$, Luciane Vilela Resende ${ }^{2}$, \\ Maria Ligia de Souza Silva ${ }^{3}$ Thiago Sampaio Guerra ${ }^{2}$
}

10.1590/0034-737X201966060008

\begin{abstract}
Considering that the beneficial effects of silicon on human health and it's accumulation in plants are little explored, studies of mineral nutrition in non-conventional vegetables are extremely relevant. Thus, the objective of this work was to identify non-conventional vegetables responsive to silica fertilization and evaluate the effect of fertilization on the content and accumulation of $\mathrm{Si}$ and macronutrients in these plants. The experiment followed a 4 x 5 factorial design, with four species of non-conventional vegetables (Rumex acetosa L., Amaranthus retroflexus L., Sonchus oleraceus L. and Stachys byzantina $)$ and five doses of $\operatorname{Si}\left(0,25,50,100\right.$ and $\left.150 \mathrm{mg} \mathrm{dm}^{-3}\right)$. The relative chlorophyll index, the fresh and dry matter masses, the content and accumulation of $\mathrm{Si}$ and macronutrients were evaluated. The species A. retroflexus, $S$. oleraceus. and S. byzantina showed the highest contents and accumulation of Si. The application of doses above $100 \mathrm{mg} \mathrm{dm}^{-3}$ promoted the highest silicon content estimated for the species. The species A. retroflexus, $R$. acetos $a$ and $S$. byzantina are non-silicon accumulators, whereas $S$. oleraceus is intermediate.
\end{abstract}

Keywords: Amaranthus retroflexus L.; Rumex acetosa L.; Stachys byzantine, Sonchus oleraceus L.; minerals.

\section{INTRODUCTION}

Silicon $(\mathrm{Si})$ is the second most abundant element in the Earth's crust wich the average content in soil ranging from 25 to $35 \%$; however, in soils in which the weathering process is very strong can contain less than $1 \%$ (Lima Filho, 2010). For plants, the main source of $\mathrm{Si}$ in soil is available in the form of silicic acid $\left(\mathrm{H}_{4} \mathrm{SiO}_{4}\right)($ Epstein \& Bloom, 2006).

Although Si is not characterized as essential for plants, several studies show that their growing performance in environments with Si availability is favored despite their stress, and are superior in comparison to those grown in soils with a low availability of this mineral. This fact is mainly attributed to Si's capacity to promote tolerance to biotic and abiotic stresses in plants (Zanetti et al., 2016; Peixoto \& Junior, 2017).

Another important characteristic of Si which has aroused the curiosity of researchers concerns the essentiality of the mineral and its benefits to human health. It performs several functions in the human body, with the maintenance of bone health being undoubtedly the most relevant and of greater interest by scholars, especially due to the large incidence and diversity of diseases related to postmenopausal women and the elderly (Rodella et al., 2014). Therefore, $\mathrm{Si}$ is an important mineral for both plants and humans. Vegetables can be favored by silicate fertilization, as well as becoming an excellent source of $\mathrm{Si}$ in human diets.

\footnotetext{
Submitted on December $10^{\text {th }}, 2018$ and accepted on October $12^{\text {th }}, 2019$.

${ }^{1}$ This work is part of the first author of the master's thesis.

${ }^{2}$ Universidade Federal de Lavras, Departamento de Agricultura, Lavras, Minas Gerais, Brazil. claudioubajara@hotmail.com; douglascorrea@ymail.com; luciane.vilela@dag.ufla.br; thiagosampaioguerra@ hotmail.com

${ }^{3}$ Universidade Federal de Lavras, Departamento de Ciências do Solo, Lavras, Minas Gerais, Brazil. marialigia.silva@des.ufla.br

${ }^{4}$ Universidade José do Rosário Vellano - UNIFENAS, Minas Gerais, Brasil. luis.silva@unifenas.br

*Corresponding author: douglascorrea@ymail.com
} 
In this context of healthy eating, non-conventional vegetables have been gaining space and becoming an option as a source of vitamins, minerals, proteins and fiber (Silva et al., 2018c). These species include a series of plants that have been widely appreciated as part of family meals, but over the years have been forgotten or devalued, mainly by the rural exodus, which led people to consume more processed foods (Silva et al., 2018a; Silva et al., 2018b; Xavier et al., 2019).

Despite the beneficial effects of $\mathrm{Si}$ on various crops and its importance to human health, little is known about its influence on the growth and mineral composition of plants, especially those characterized as nonconventional, which have an important contribution to diet, economy, and culture of traditional rural communities. The hypothesis is that plants may be favored with silicate fertilization and that non-conventional vegetables enriched with this element may supply the need for populations in situations of food insecurity. Thus, the objective of this work is to identify non-conventional vegetables responsive to silicone fertilization and evaluate the effect of fertilization on the content and accumulation of Si and macronutrients in these plants.

\section{MATERIALS AND METHODS}

The experiment was performed during the 2016 crop year, in Lavras, in the southern part of the State of Minas Gerais, Brazil, located at $21^{\circ} 14^{\prime}$ 'S , $45^{\circ} 00^{\prime} \mathrm{W}$ and $918.8 \mathrm{~m}$ of altitude. The climate of the region is Cwa (mesothermal) with dry winter and rainy summer, according to Köppen classification (Álvares et al., 2013).

The experiment followed a 4 x 5 factorial design, with four species of non-conventional vegetables, sorrel (Rumex acetosa L.) redroot amaranth (Amaranthus retroflexus L.), common sowthistle (Sonchus oleraceus L.) and lamb's ears (Stachys byzantina), being submitted to five levels of silicate fertilization $(0,25,50,100$ and 150 $\mathrm{mg} \mathrm{dm} \mathrm{m}^{-3}$ ), totaling 20 treatments, with four replications and one plant per experimental plot. The tests were performed in a greenhouse using a completely randomized design, assuming homogeneous experimental conditions.

The $\mathrm{Si}$ source used in the experiment labeled a concentration of $98 \% \mathrm{SiO}_{2}$ and $6.5 \%$ soluble $\mathrm{Si}$. The $\mathrm{Si}$ doses were applied only once directly to the substrate through surface incorporation, seven days before the transplanting seedlings.

The studied species derived from the germplasm collection of non-conventional vegetables of the Federal University of Lavras (UFLA). The seedlings of $A$. retroflexus and $S$. oleraceus were produced from seeds, in 200-cell plastic trays and commercial substrate based on pinus bark. Leaf fertilization was performed three times in the seedlings with leaf fertilizer, source of macro and micronutrients, in the dosage of $1 \mathrm{ml} \mathrm{L}^{-1}$ of water. The seedlings were transplanted to pots when they reached 8 $\mathrm{cm}$ in length. The $R$. acetosa and S. byzantina are commonly propagated vegetatively. Thus, the propagules were transplanted directly into the pots containing substrate, using vigorous and healthy offspring.

Plastic pots with a capacity of $3 \mathrm{dm}^{3}$ of soil were used, in which a single plant was conditioned. The used substrate consisted of an uncultivated soil collected in the 0 to $20 \mathrm{~cm}$ layer, classified as a dystrophic red latosol (Santos et al., 2013) with the following characteristics: $\mathrm{pH}$ $\left(\right.$ in $\left.\mathrm{H}_{2} \mathrm{O}\right)=5.4$; exchangeable $\mathrm{Al}=0.10 \mathrm{cmol}_{\mathrm{c}} \mathrm{dm}^{-3} ; \mathrm{Ca}^{2+}=$ $2.12 \mathrm{cmol} \mathrm{dm}^{-3} ; \mathrm{Mg}^{2+}=0.74 \mathrm{cmol} \mathrm{dm}^{-3} ; \mathrm{P}-$ Mehlich $=2.91$ $\mathrm{mg} \mathrm{dm}{ }^{-3} ; \mathrm{K}^{+}=70 \mathrm{mg} \mathrm{dm}^{-3} ;$ Organic matter $=1.64 \mathrm{dag} \mathrm{kg}^{-1}$; $\mathrm{H}+\mathrm{Al}=3.35 \mathrm{cmol} \mathrm{dm}^{-3} ; \mathrm{V}=47.67 \%$; Sum of bases $=3.04$ $\mathrm{cmol}_{\mathrm{c}} \mathrm{dm}^{-3} ; \mathrm{t}=3.14 \mathrm{cmol}_{\mathrm{c}} \mathrm{dm}^{-3} ; \mathrm{T}=6.39 \mathrm{cmol}_{\mathrm{c}} \mathrm{dm}^{-3} ; \mathrm{m}=$ $3.18 \%$; Soil texture $=$ sandy clay.

Correction of soil acidity was performed by applying $2.4 \mathrm{~g}$ of dolomitic limestone per pot to raise base saturation to $70 \%$. The soil was incubated for 15 days, with moisture at $60 \%$ of water-holding capacity. There is no fertilizer recommendation for the species used in the study. Thus, it was decided that the fertilization of the species would be performed according to the recommended by Malavolta (1981) for the cultivation of potted plants. All plants were fertilized with $900 \mathrm{mg}$ of nitrogen, $450 \mathrm{mg}$ of potassium and $600 \mathrm{mg}$ of phosphorus per pot. Nitrogen and potassium were applied in quotas (three times), being the first fertilization performed five days after transplanting seedlings, and the following fertilizations every 10 days in between one another. Phosphorus was applied in a single dose when the plants were established in the pots. The fertilizers' urea, potassium chloride, and monoammonium phosphate, respectively, were used as sources of nitrogen, potassium, and phosphorus.

Hand weeding was performed weekly in pots to prevent competition with weeds. Due to the plant's health throughout the experimental period, no intervention was necessary to control pests and diseases. Drip irrigation was performed according to the need of the plants.

The determination of the relative chlorophyll index (SPAD index) was performed using a SPAD-502 chlorophyll meter. The method is characterized as nondestructive and performed directly in the field. Measurements were made 35 days after transplanting on the fully developed leaves of the upper third of plants. The analysis was performed near the harvest time due to a longer accumulation time of said mineral in those plants, the moment in which it would be possible to identify any effect of $\mathrm{Si}$ in the parameter. 
To measure fresh and dry matter masses, those plants produced from seeds were harvested when they reached a reproductive stage (flowering), a period of higher demand and accumulation of minerals, whereas the plants vegetatively propagated were harvested when the first senescence leaves emerged. Soon after the harvest, the shoot of plants (leaves and branches) was weighed for measuring of fresh matter mass. Subsequently, all plants were washed individually in running water, rinsed with distilled water and placed individually in properly identified paper bags. All materials were transferred to a convection oven at a temperature of $65^{\circ} \mathrm{C}$, where they remained until all plants reached constant weight. Afterward, the dry matter of each plant was determined.

For determination of the concentration of $\mathrm{Si}$ and macronutrients, the shoot of the dehydrated plants was milled individually in a Thomas Wiley mill. The Si contents of plants were determined through the colorimetric technique, a methodology described by Korndörfer et al. (2004). The Si accumulation was obtained by multiplying each plant's dry mass by its Si content. Through the methodology described by Silva (2009), the phosphorus content of the plants was determined by colorimetry, potassium by flame photometry, and calcium and magnesium by atomic absorption spectrophotometry.

For the variables Si content and $\mathrm{Si}$ accumulation that showed significance by the $\mathrm{F}$ test $(p<0.05)$, regression equations were fitted. According to the equations, doses that provided higher content and $\mathrm{Si}$ accumulation in the evaluated species were estimated. Additionally, to identify the existing relationships between $\mathrm{Si}$ and other variables, an exploratory factorial analysis was performed. The statistical tests were performed through the development of scripts in the R (R Core Team) software for public use, through the package MVar.pt, version 1.9.6 (Ossani \& Cirilo, 2017).

\section{RESULTS AND DISCUSSIONS}

\section{Si content and accumulation in non-conventional vegetable species}

Non-conventional vegetable species showed different Si content with the different applied doses of the mineral. The $S$. oleraceus showed a higher Si content at $0 \mathrm{mg} \mathrm{dm}^{-3}\left(3.95 \pm 0.22 \mathrm{~g} \mathrm{~kg}^{-1}\right)$, followed by $R$. acetosa $\left(3.32 \pm 0.04 \mathrm{~g} \mathrm{~kg}^{-1}\right)$. At the higher doses, S. oleraceus kept standing out in relation to the Si content (dose $25 \mathrm{mg} \mathrm{dm}^{-}$ ${ }^{3}$ at $4.60 \pm 0.21 \mathrm{~g} \mathrm{~kg}^{-1}$ Si content; $50 \mathrm{mg} \mathrm{dm}^{-3}$ at $5.39 \pm 0.25$ $\mathrm{g} \mathrm{kg}^{-1} ; 100 \mathrm{mg} \mathrm{dm}^{-3}$ at $5.38 \pm 0.03 \mathrm{~g} \mathrm{~kg}^{-1}$; and $150 \mathrm{mg} \mathrm{dm}^{-3}$ at $5.06 \pm 0.12$ ). However, it varied according to the applied dose for the other species. The higher the applied doses of the material, the higher the Si contents; however, but very high doses showed an antagonistic effect, reducing the Si content in the plants (Figure 1).

Based on the derivatives of calculated equations, $\mathrm{Si}$ doses that would promote higher Si content in the species could be estimated. $240 \mathrm{mg} \mathrm{dm}^{-3}$ was determined as the dose responsible for the highest $\mathrm{Si}$ content estimated for $R$. acetosa (4.5 $\mathrm{g} \mathrm{kg}^{-1}$ in the dry matter). For A. retroflexus, the application of $115 \mathrm{mg} \mathrm{dm}^{-3}$ promoted a Si content of $3.44 \mathrm{~g} \mathrm{~kg}^{-1}$ in dry matter. The application of $122.50 \mathrm{mg} \mathrm{dm}^{-}$ ${ }^{3} \mathrm{Si}$ in S. byzantina and $277.50 \mathrm{mg} \mathrm{dm}^{-3}$ in S. oleraceus promoted the maximum estimated levels of 4.52 and $5.43 \mathrm{~g}$ $\mathrm{kg}^{-1} \mathrm{Si}$ in dry matter respectively.

The variation in the content and absorption capacity of Si within each species is influenced by genetics, and such variation is higher among different species due to the absorption mechanisms used by each (Hodson et al., 2005; Liang et al., 2015). There are three possible mechanisms of Si absorption by plants. Active absorption, in which $\mathrm{Si}$ absorption is fast, subsidized by $\mathrm{Si}$ transporters; passive absorption, which occurs in the same direction as the plant's transpiration stream, with $\mathrm{Si}$ absorption equal to water absorption; and Si-excluding plants, in which $\mathrm{Si}$ absorption is lower than water absorption by plants (Takahashi et al., 1990).

The presence or absence of Si transporters, as well as their higher or lower density in the plants, can explain the differences among species regarding the efficiency of Si absorption. The rate of transpiration of plants is another favorable factor for Si absorption; the higher the rate, the greater the absorption and accumulation efficiency of the mineral (Jones \& Handreck, 1967).

A similar result was obtained by D'Imperio et al. (2016), which promoted an increase in Si contents in six species of leaf vegetables cultivated in a hydroponic system by applying 50 and $100 \mathrm{mg} \mathrm{dm}^{-3}$ of $\mathrm{Si}$ in the nutrient solution. The experiment found no significant difference in the mineral content among the studied plants. The bioavailability values quantified by the authors in an in vitro digestion process are much higher in plants that received $\mathrm{Si}$ via nutrient solution when compared to the control treatment $\left(0 \mathrm{mg} \mathrm{dm}^{-3}\right)$.

The absorption of $\mathrm{Si}$ in rice plants varies depending on the applied doses of Si (Pati et al., 2016). Although Si is an abundant element in the soil, the concentration of minerals available for plants is usually low, and its absorption depends on the external supply (Jawahar \& Vaiyapuri, 2013).

The availability of silicic acid to plants may decrease as a function of the acid polycondensation, producing oligomeric silicic acid and colloidal particles of hydrated silica $\left(\mathrm{SiO}_{2} \cdot \mathrm{H}_{2} \mathrm{O}\right)$, which are caused by high concentration of $\mathrm{Si}$ in soil. Another relevant aspect are adsorption and 
desorption processes of $\mathrm{Si}$ in soil reactive materials, mainly sesquioxides, reducing or increasing mineral availability in soil (Jones \& Handreck, 1967).

The species are classified into three groups: $\mathrm{Si}$ accumulators, generally monocotyledons with Si leaf content, which can exceed $10 \mathrm{~g} \mathrm{~kg}^{-1}$ of mineral in dry matter; Si non-accumulators, generally leguminous, with Si content lower than $5 \mathrm{~g} \mathrm{~kg}^{-1}$; and the intermediates, with Si content higher than $5 \mathrm{~g} \mathrm{~kg}^{-1}$, but lower than $10 \mathrm{~g} \mathrm{~kg}^{-1}$ (Takahashi et al., 1990).

With respect to the $\mathrm{Si}$ accumulation, S. byzantina stood out, showing better performance in all applied doses of Si. The R. acetosa species showed an accumulation capacity inferior to $S$. byzantina, but superior to the others (Figure 2). The S. oleraceus presented an intermediate result at all doses, whereas A. retroflexus was the species that showed the lowest accumulation of Si. Plants with higher leaf volume, such as R. acetosa and $S$. byzantina show greater capacity to accumulate Si. Similarly as to $\mathrm{Si}$ content, it was observed that $\mathrm{Si}$ accumulation is increasing until a determined dose, but reducing at high doses.

Based on the derivatives of equations calculated for the determination of doses that would provide the best estimated results for $\mathrm{Si}$ accumulation, it was indicated that, by applying $119 \mathrm{mg} \mathrm{dm}^{-3}, R$. acetosa would reach a maximum accumulation of $96.94 \mathrm{mg} \mathrm{Si} \mathrm{plant}^{-1}$. The dose of
$125.88 \mathrm{mg} \mathrm{dm}^{-3}$ would promote maximum accumulation of $73.17 \mathrm{mg} \mathrm{Si} \mathrm{plant}^{-1}$ in A. retroflexus. Accumulation of up to $109.78 \mathrm{mg} \mathrm{Si} \mathrm{plant}^{-1}$ in $S$. byzantina would be possible with the application of $249 \mathrm{mg} \mathrm{dm}^{-3} \mathrm{Si}$. The application of $462.5 \mathrm{mg} \mathrm{dm}^{-3} \mathrm{Si}$ promoted a higher accumulation of $\mathrm{Si}$ in $\mathrm{Si}$ in $R$. acetosa. However, considering that it was a dose well outside the range of evaluated doses, the calculation was performed with a maximum dose of $150 \mathrm{mg} \mathrm{dm}^{-3}$, with S. oleraceus plants showing an estimated maximum $\mathrm{Si}$ accumulation of $77 \mathrm{mg}$ plant $^{-1}$.

Although all plants contain $\mathrm{Si}$, they show great variation in their accumulation capacity of this mineral in their tissues. The difference in Si accumulation among species may be influenced by the root ability to intercept the mineral. The Si concentrations may range from $1 \mathrm{~g} \mathrm{~kg}^{-}$ ${ }^{1}$ to over $100 \mathrm{~g} \mathrm{~kg}^{-1}$ of dry matter (Ma and Takahashi, 2002).

Doses that provided higher or lower content and accumulation of Si were different according to species. As the species in the present study are Si nonaccumulators, it is assumed that mineral absorption occurs through a passive process that depends on the transpiration capacity of plants, besides root interception capacity of $\mathrm{Si}$ in each one. Si absorption is higher in the basal regions of roots, being the apical meristem and the root elongation zone less efficient in Si absorption (Yamaji and Ma, 2007).

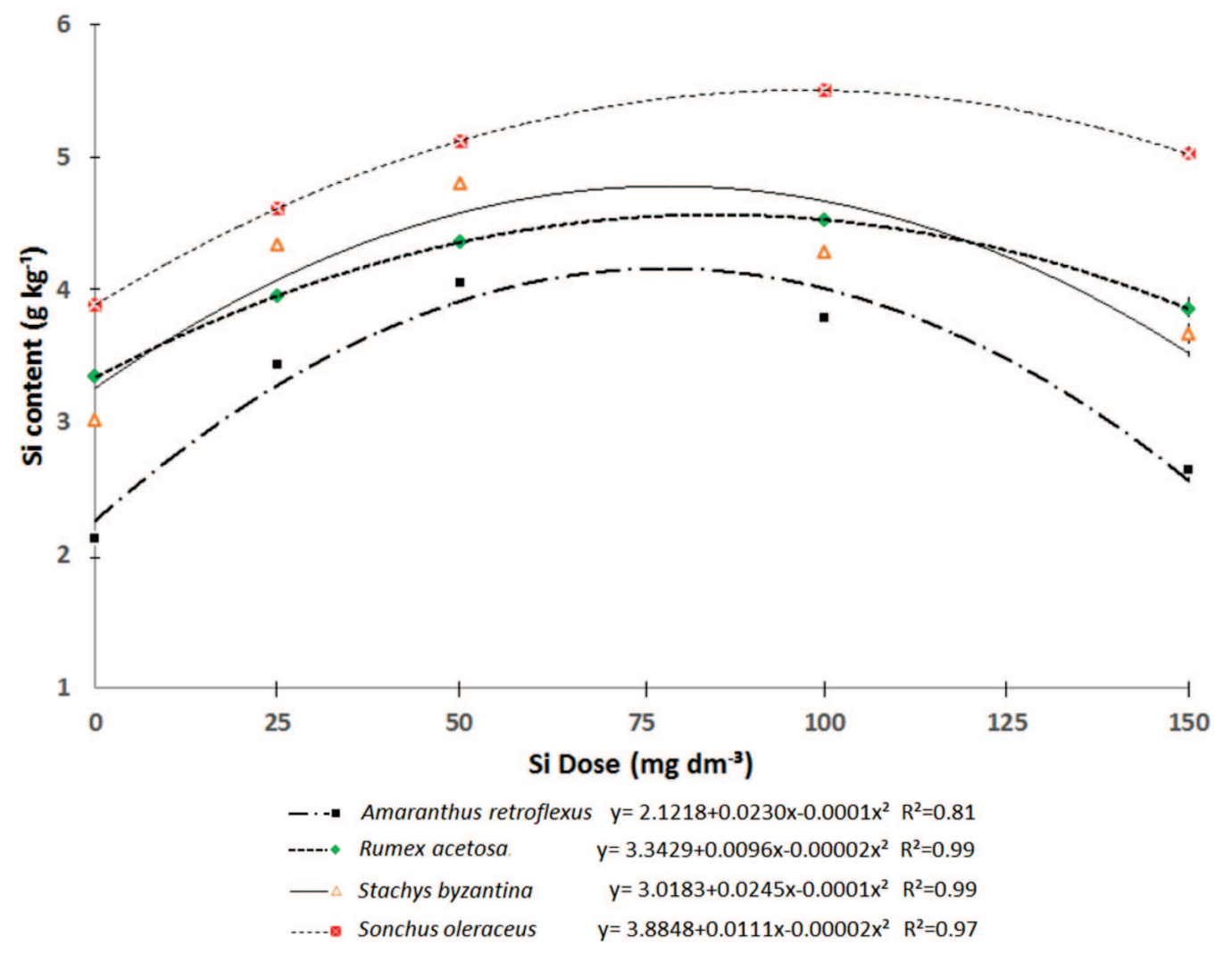

Figure 1: Average Si content in four non-conventional vegetable species as a function of silicon application. 


\section{Effects of Si on other minerals and on agronomic parameters}

In order to verify the relationships and effects of $\mathrm{Si}$ on other minerals and on agronomic parameters, such as biomass production, the exploratory analysis of the data was performed.

According to the exploratory factorial analysis of the R. acetosa species (Figure 3A), except for variables $\mathrm{K}$ and $\mathrm{Ca}$, which showed an inverse correlation with the others, Si positively correlated with $\mathrm{P}, \mathrm{Mg}$, fresh matter (FM), dry DM and SPAD index, i.e., the increase in Si content promotes gains in the mentioned variables and vice versa. The explanation of the total variance attributed to both factors was $84.53 \%$ (Table 1).

The variable least explained by the factorial model was phosphorus $(\mathrm{P})$, whereas the most explained was DM. These results can be verified by taking the commonality of each variable. Commonality is how much of the variance of variables is measured or explained by the extracted "f" factors. These factors are non-observed variables intended to be measured base on the observed variables.

In the exploratory factor analysis in $A$. retroflexus (Figure $3 \mathrm{~B}$ ), it is possible to identify that $\mathrm{Ca}$ and $\mathrm{FM}$ are antagonistic to each other. $\mathrm{P}$ promotes gains in the SPAD index. Both, however, cause a reduction in $\mathrm{K}$ and DM variables, and vice versa. There is a strong positive influence of $\mathrm{Si}$ on the $\mathrm{Mg}$ content and vice versa. $\mathrm{Si}$ generally has a positive effect on the content of $\mathrm{P}, \mathrm{Ca}, \mathrm{Mg}$ and SPAD index in A. retroflexus. The explanation of the total variance attributed to both factors was $73.51 \%$ (Figure 1).

Ca in S. byzantina (Figure 3C) promotes increases in FM and DM. However, the correlation is inverse with $\mathrm{Si}$, indicating its negative effect on the mentioned variables. Nevertheless, Si showed a positive effect on the contents of $\mathrm{P}$ and of the SPAD index. The explanation of the total variance attributed to both factors was $76.24 \%$ (Table 1).

For $S$. oleraceus, it was verified that $\mathrm{Si}$ increases the contents of $\mathrm{K}, \mathrm{P}, \mathrm{Ca}$ and $\mathrm{Mg}$, but reduced FM and DM (Figure 3D). The explanation of the total variance attributed to both factors was $78.65 \%$ (Table 1).

The behavior and the relationships among the variables $\mathrm{Si}, \mathrm{P}, \mathrm{K}, \mathrm{Ca}, \mathrm{Mg}, \mathrm{FM}$ and $\mathrm{DM}$ were different according to the species. The existing relationships, especially with respect to these minerals, go far beyond the chemical reactions occurring in soil, in detriment of fertilization with $\mathrm{Si}$.

The application of Si, together with complete fertilizers in rice crop, provides a higher crop yield, besides increasing the absorption of macro and micronutrients (Pati et al., 2016). In maize crop, fertilization with Si increases the absorption of minerals, increases the total soluble sugar, starch content and dry matter accumulation (Xu et al., 2016).

$\mathrm{Si}$ is considered as a functional nutrient for several crops, especially for grasses, such as rice and sugarcane, favoring the growth and development of these species (Hodson et al., 2005; Epstein \& Bloom, 2006). Si has a synergistic effect on other minerals in soil, and may increase the availability of $\mathrm{N}$ and provides higher efficiency of phosphate fertilizers up to $10 \%$, by reducing P retention in soil and increasing soluble P levels (Singh et al., 2005; Pati et al., 2016). Jongruk (2002) reported that the application of NPK fertilizers combined with Si significantly increased total N, P and K uptake of rice. Singh et al. (2005) state that the application of Si increases the uptake of $\mathrm{K}$ in rice.

In a study with lettuce culture, Kleiber et al. (2015) reported that Si nutrition did not alter the Mn content in the leaves of said culture. However, it caused a significant increase in relation to the control treatment in concentrations of $\mathrm{N}, \mathrm{P}, \mathrm{Na}, \mathrm{Fe}$ and $\mathrm{Si}$, and simultaneous decrease of $\mathrm{Zn}$ and $\mathrm{Cu}$ contents.

In contrast to the results obtained in the study, Lu et al. (2017) found that the biomass of the prince's-feather (A. hypochondriacus L.) increased incrementally inasmuch as the doses of calcium silicate applied to soil also increased. However, there was no more positive effect on biomass at higher doses.

The positive effects of $\mathrm{Si}$ on yield and quality of several crops have been widely reported. The effect is more evident in grasses such as rice, maize, sugarcane, pearl millet and sorghum, among others (Liang et al., 2015), since they are characterized as $\mathrm{Si}$ accumulators. The beneficial effects of this mineral on dicotyledons such as cotton, soybean, cucumber and some fruits, have been proven and are being increasingly investigated.

Wang et al. (2016) stated that the yield of apples was significantly increased in detriment of the application of Si. Chagas et al. (2016), in a study with rice and pearl millet cultivated in the Brazilian savanna, reported that the application of Si increases the yield of these crops. Costa et al. (2015) reported increased diameter of the Palmer mangoes associated with the application of Si. It is possible to state that the effects of Si on crops are positive and it is, therefore, a very promising mineral for increasing yield, quality, health and nutritional quality of several plant species.

In studies performed in the last decade, the positive effects of Si on chlorophyll biosynthesis were confirmed, especially in plants growing under stress conditions. For instance, the application of $\mathrm{Si}+\mathrm{Cd}$ caused an increase in the content of chlorophyll $\mathrm{a}$ and $\mathrm{b}$ and carotenoids in relation to the treatment in which only $\mathrm{Cd}$ was applied in 
Table 1: Exploratory factor analysis considering the variables phosphorus (P), potassium (K), calcium (Ca), magnesium (Mg), silicon (Si), silicon accumulation (plant), fresh mass (FM), dry mass (DM) and SPAD index, as a function of silicon fertilization in the species $R$. acetosa, A. retroflexus, S. byzantina and S. oleraceus

\begin{tabular}{|c|c|c|c|c|c|c|c|c|c|c|c|}
\hline \multirow{2}{*}{ Factor } & \multicolumn{10}{|c|}{ R. acetosa } & \multirow[b]{2}{*}{$\%$} \\
\hline & $\mathbf{Y}$ & $\mathbf{K}$ & $\mathrm{Ca}$ & $\mathrm{Mg}$ & Si & Accumulation of $\mathrm{Si}$ & FM & DM & SPAD index & $\lambda$ & \\
\hline 1 & 0.190 & -0.708 & -0.717 & 0.287 & 0.845 & 0.964 & 0.716 & 0.781 & 0.550 & 4.200 & 64.69 \\
\hline 2 & -0.148 & 0.212 & 0.054 & -0.244 & -0.407 & 0.061 & 0.590 & 0.581 & -0.552 & 1.288 & 19.84 \\
\hline Com.* & 0.058 & 0.546 & 0.517 & 0.142 & 0.879 & 0.932 & 0.860 & 0.947 & 0.607 & 5.488 & 84.53 \\
\hline S.V.** & 0.942 & 0.454 & 0.483 & 0.858 & 0.121 & 0.068 & 0.140 & 0.053 & 0.393 & - & - \\
\hline \multirow{2}{*}{ Factor } & \multicolumn{10}{|c|}{ A. retroflexus } & \\
\hline & $\mathbf{Y}$ & $\mathbf{K}$ & $\mathrm{Ca}$ & Mg & Si & Accumulation of $\mathrm{Si}$ & FM & DM & SPAD index & $\lambda$ & $\%$ \\
\hline 1 & 0.467 & -0.636 & 0.700 & 0.185 & 0.653 & 0.535 & -0.730 & -0.531 & 0.508 & 2.933 & 40.82 \\
\hline 2 & 0.029 & -0.422 & 0.237 & -0.720 & -0.727 & -0.836 & -0.341 & -0.268 & 0.425 & 2.349 & 32.69 \\
\hline Com.* & 0.219 & 0.582 & 0.546 & 0.553 & 0.955 & 0.984 & 0.649 & 0.354 & 0.439 & 5.282 & 73.51 \\
\hline S.V.** & 0.781 & 0.418 & 0.454 & 0.447 & 0.045 & 0.016 & 0.351 & 0.646 & 0.561 & - & - \\
\hline \multirow{2}{*}{ Factor } & \multicolumn{10}{|c|}{ S. byzantina } & \\
\hline & $\mathbf{Y}$ & $\mathbf{K}$ & $\mathbf{C a}$ & Mg & $\mathbf{S i}$ & Accumulation of $\mathrm{Si}$ & FM & DM & SPAD index & $\lambda$ & $\%$ \\
\hline 1 & 0.073 & -0.248 & -0.744 & -0.681 & 0.911 & 0.737 & -0.855 & -0.769 & 0.483 & 4.012 & 60.11 \\
\hline 2 & 0.275 & -0.279 & -0.485 & -0.546 & -0.404 & -0.046 & 0.019 & 0.463 & -0.099 & 1.076 & 16.12 \\
\hline Com.* & 0.081 & 0.139 & 0.789 & 0.762 & 0.993 & 0.545 & 0.732 & 0.806 & 0.243 & 5.089 & 76.24 \\
\hline S.V.** & 0.919 & 0.861 & 0.211 & 0.238 & 0.007 & 0.455 & 0.268 & 0.194 & 0.757 & - & - \\
\hline \multirow{2}{*}{ Factor } & \multicolumn{10}{|c|}{ S. oleraceus } & \\
\hline & $\mathbf{Y}$ & $\mathbf{K}$ & $\mathbf{C a}$ & $\mathrm{Mg}$ & Si & Accumulation of $\mathrm{Si}$ & FM & DM & SPAD index & $\lambda$ & $\%$ \\
\hline 1 & -0.656 & -0.888 & -0.669 & -0.483 & -0.873 & -0.484 & 0.824 & 0.727 & 0.169 & 4.133 & 57.37 \\
\hline 2 & -0.050 & -0.058 & -0.469 & -0.290 & -0.026 & -0.640 & -0.369 & -0.665 & -0.485 & 1.533 & 21.28 \\
\hline Com.* & 0.433 & 0.792 & 0.668 & 0.317 & 0.762 & 0.643 & 0.816 & 0.971 & 0.264 & 5.666 & 78.65 \\
\hline S.V.** & 0.567 & 0.208 & 0.332 & 0.683 & 0.238 & 0.357 & 0.184 & 0.029 & 0.736 & - & - \\
\hline
\end{tabular}

* Commonality, ** Specific variances, Variance,

Coefficient of factor loading: $<0.3$ (weak factor loading); 0.3 d" FL $<0.5$ (low factor loading); 0.5 d" FL $<0.7$ (moderate factor loading); 0.7 d" FL $<0.9$ (high factor loading); 0.9 d" FL $<1.0$ (strong factor loading). 


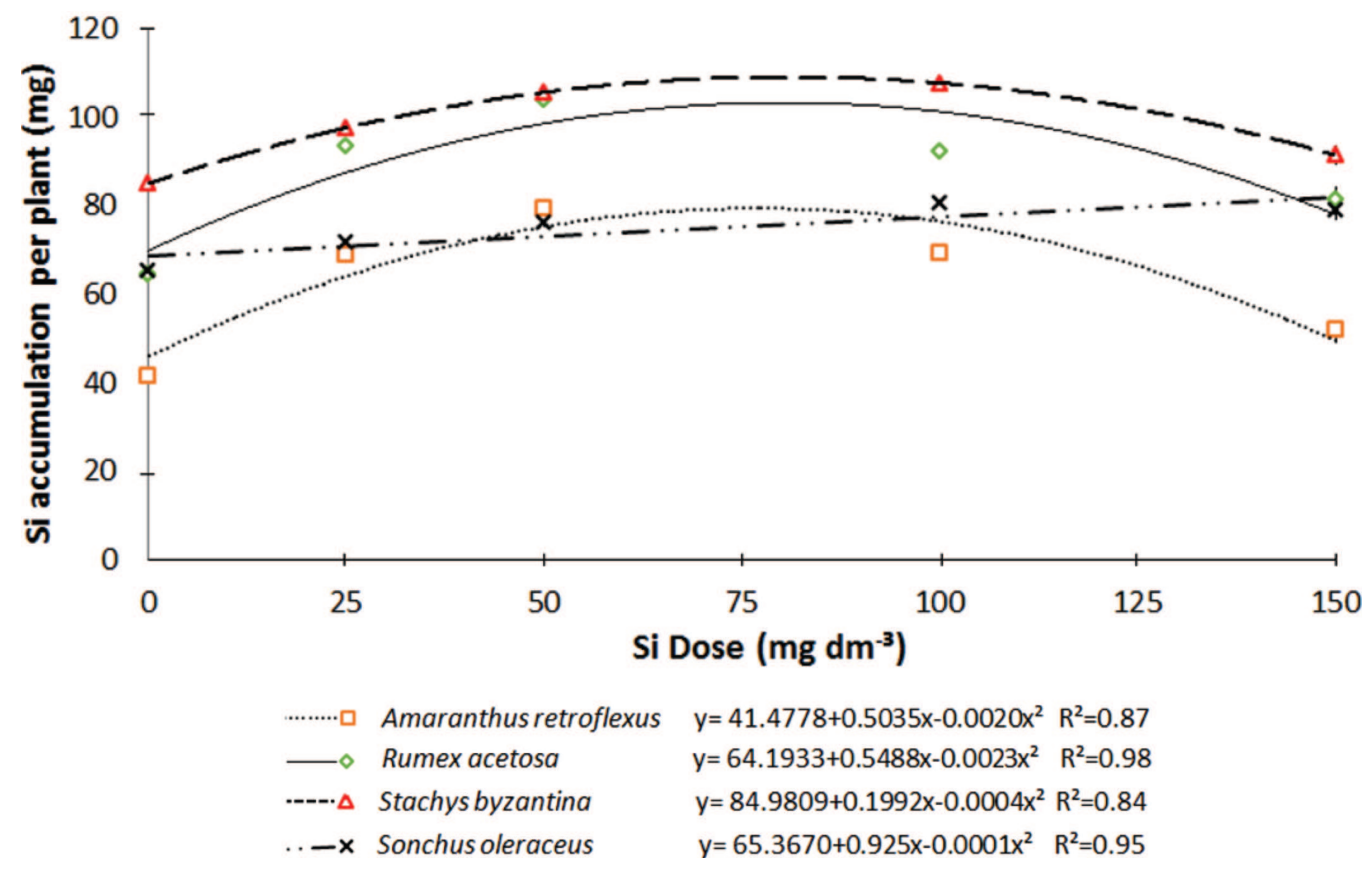

Figure 2: Accumulation of $\mathrm{Si}$ in four non-conventional vegetable species as a function of silicon application.
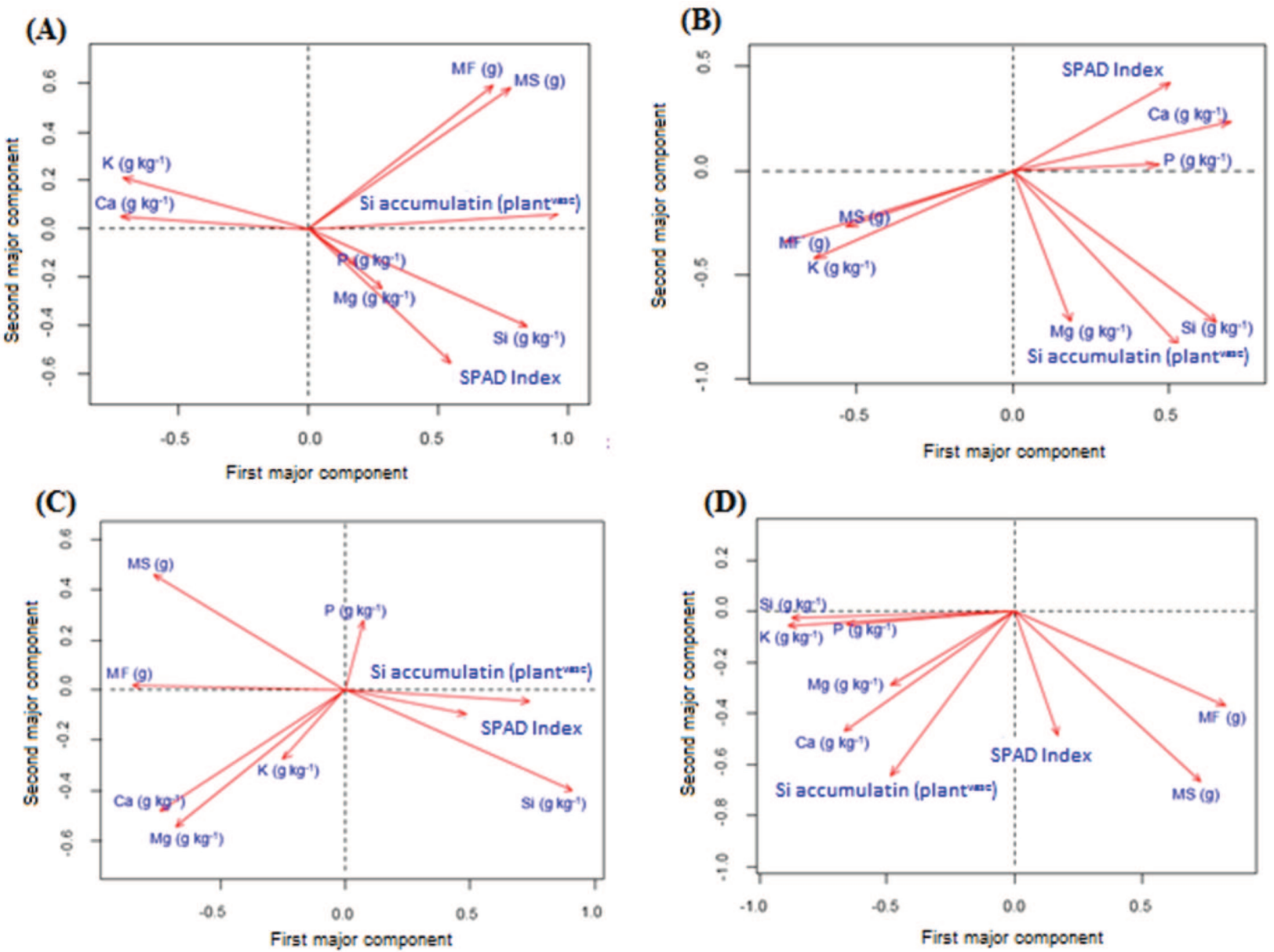

Figure 3: Exploratory factor analysis considering the variables, phosphorus $(\mathrm{P})$, potassium $(\mathrm{K})$, calcium $(\mathrm{Ca}), \mathrm{magnesium}(\mathrm{Mg})$, silicon ( $\mathrm{Si}$ ), silicon accumulation (plant ${ }^{\text {pot }}$ ), fresh mass (FM), dry mass (DM) and SPAD index, as a function of silicon fertilization in the species (A) R. acetosa, (B) A. retroflexus, (C) S. byzantina and (D) S. oleraceus.

Rev. Ceres, Viçosa, v. 66, n.6, p. 470-478, nov/dec, 2019 
the maize crop (Mihalièová Malèovská et al. 2014). In the same culture, Xu et al. (2016) reported that Si fertilization increases grain yield by increasing photosynthesis and the activity of antioxidant enzymes in wheat (Hussain et al. 2015) and cucumber (Jianpeng et al. 2010).

Photosynthetic pigments are important properties regarding biomass production by plants. Stressed plants undergo chlorophyll reduction, which is attenuated by the application of $\mathrm{Si}$, favoring the increase of chlorophyll. Although the species of the present study did not undergo any type of induced stress, there was a positive effect of silica fertilization on the chlorophyll content (Sattar et al., 2016).

\section{CONCLUSIONS}

Silicate fertilization caused an effect on silicon content and accumulation in non-conventional vegetables. In general, Si content and accumulation were increasing with higher mineral doses, although very high doses had an antagonistic effect of reducing the response in plants. Thus, it is estimated that the application of $240 ; 115$; 122.50; and $277.50 \mathrm{mg} \mathrm{dm}^{-3}$ provided the highest estimated silicon contents for R. acetosa, A. retroflexus, S. byzantina and $S$. oleraceus, respectively. Among these species only $S$. oleraceus is characterized as an intermediate accumulator of $\mathrm{Si}$.

For the effects of Si on other minerals and agronomic parameters it was observed that silicon fertilization does not have a positive effect on green and dry matter of nonconventional vegetables. However, it generally improves phosphorus, calcium, potassium, magnesium and chlorophyll contents.

\section{REFERENCES}

Álvares CA, Stape JL, Sentelhas PC, Gonçalves JLM \& Sparovek G (2013) Koppen's climate classification map for Brazil. Meteorologische Zeitschrift, 22:711-728.

Chagas RDS, Muraoka T, Korndorfer GH \& Camargo MS (2016) Silicon fertilization improve yield and quality of rice and pearl millet in cerrado soils. Bioscience Journal, 32:899-907.

Costa IJS, Pereira MCT, Mizobutsi GP, Maia VM, Silva JF, Oliveira JAA, Oliveira MB, Souza VNR, Nietsche S, Santos EF \& Korndorfer GH (2015) Influence of silicon fertilization on 'Palmer' mango tree cultivation. Acta Horticulturae, 1075:229234.

D'imperio M, Renna M, Cardinali A, Buttaro D, Santamaria P \& Serio F (2016) Silicon biofortification of leafy vegetables and its bioaccessibility in the edible parts. Journal of the Science of Food and Agriculture, 96:751-756.

Epstein E \& Bloom AJ (2006) Nutrição Mineral de Plantas: Princípios e Perspectivas. Londrina, Planta. 403p.

Jianpeng F, Qinghua S, Xiufeng W, Min W, Fengjuan Y \& Huini X (2010) Silicon supplementation ameliorated the inhibition of photosynthesis and nitrate metabolism by cadmium $(\mathrm{Cd})$ toxicity in Cucumis sativus L. Scientia Horticulturae, 123:521-530.
Hodson MJ, White PJ, Mead A \& Broadley MR (2005) Phylogenetic variation in the silicon composition of plants. Annals of Botany, 96:1027-1046.

Hussain I, Ashraf MA, Rasheed R, Asghar A, Sajid MA \& Iqbal M (2015) Exogenous application of silicon at the boot stage decreases accumulation of cadmium in wheat (Triticum aestivum L.) grains. Brazilian Journal of Botany, 38:223-234.

Jawahar S \& Vaiyapuri V (2013) Effect of sulphur and silicon fertilization on yield, nutrient uptake and economics of rice. International Reseach Jounal Chemistry, 03:35-43.

Jones LHP \& Handreck KA (1967) Silica in soils, plants, and animals. Advances in Agronomy, 19:107-149.

Jongruk C (2002) Effect of application of chemical fertilizer in combination with silicon on yield and nutrient uptake of rice in an acid sulfate soils. In: World Congress of Soil Science, Bangkok. Anais, International Union of Soil Sciencesp. p.14-21.

Kleiber T, Calomme M \& Borowiak K (2015) The effect of cholinestabilized orthosilicic acid on microelements and silicon concentration, photosynthesis activity and yield of tomato grown under Mn stress. Plant Physiology Biochemistry, 96:180188 .

Korndörfer GH, Pereira HS \& Nolla A (2004) Análise de silício: solo, planta e fertilizante. Uberlândia, GPSi-ICIAG-UFU. 34p.

Liang Y, Nikolic M, Bélanger R, Gong H \& Song A (2015) Silicon in agriculture: from theory to practice. New York, Springer. $235 \mathrm{p}$.

Lima Filho OF (2010) Aspectos gerais sobre o silício em solos, plantas e animais. In: Rodrigues FA (Ed.) Silício na agricultura. Viçosa, UFV. p.47-60.

Lu H, Li Z, Wu J, Shen Y, Li Y, Zou B, Tang Y \& Zhuang P (2017) Influences of calcium silicate on chemical forms and subcellular distribution of cadmium in Amaranthus hypochondriacus L. Scientific Reports, 07:01-09.

Ma JF \& Takahashi E (2002) Soil, fertilizer, and plant silicon research in Japan. New York, Elsevier. 294p.

Malavolta E (1981) Manual de química agrícola: adubos e adubação. $3^{a}$ ed. São Paulo, Ceres. 527p.

Mihalièová Malèovská S, Duèaiová Z, Maslaòáková I \& Baèkor M (2014) Effect of silicon on growth, photosynthesis, oxidative status and phenolic compounds of maize (Zea mays L.) grown in cadmium excess. Water, Air \& Soil Pollution, 225:2056.

Ossani PC \& Cirillo MA (2017) MVar.pt: Análise Multivariada. R Package Version 1.9.6. 2017. Available at: <https://cran.rproject.org/web/packages/MVar.pt/index.html>. Accessed on: March $10^{\text {th }}, 2017$.

Pati S, Pal B, Badole S, Hazra GC \& Mandal B (2016) Effect of silicon fertilization on growth, yield, and nutrient uptake of rice. Communications in Soil Science and Plant Analysis, 47:284-290.

Peixoto ML \& Junior ALB (2017) Associação entre genótipos de feijoeiro, silício e nim no controle da mosca-branca Bemisia tabaci (Gennadius, 1889) biótipo B (Hemiptera: Aleyrodidae). Revista Ceres, 64:376-383.

Rodella LF, Bonazza V, Labanca M, Lonati C \& Rezzani R (2014) A reviewof the effects of dietary silicon intake on bone homeostasis and regeneration. The Journal of Nutrition, Health and Aging, 18:820-826.

Santos HG, Jacomine PKT, Anjos LHC, Oliveira VA, Oliveira JB, Coelho MR, Lumbreras JF \& Cunha TJF (2013) Sistema brasileiro de classificação de solos. $3^{\mathrm{a}}$ ed. Brasília, Embrapa. 286p. 
Sattar A, Cheema MA, Ali H, Sher A, Ijaz M, Hussain M, Hassan W \& Abbas T (2016) Silicon mediates the changes in water relations, photosynthetic pigments, enzymatic antioxidants activity and nutrient uptake in maize seedling under salt stress. Grassland Science, 62:262-269.

Silva FC (2009) Manual de análises químicas de solos, plantas e fertilizantes. $2^{a}$ ed. Brasília, Embrapa. 627p.

Silva LFL, Souza DC, Resende LV, Gonçalves WM, Costa GM \& Martins IA (2018a) Mineral nutrition, planting density, biometric and phenological characterization of the lamb's ear. Magistra, 29:192-199.

Silva LFL, Souza DC, Resende LV, Gonçalves WM, Pereira TA \& Vieira SD (2018b) Nutrição mineral, densidade de plantio, caracterização biométrica e fenológica de Rumex acetosa L. Ciências Agrárias, 41:129-137.

Silva LFL, Souza DC, Resende LV, Nassur RCMR, Samartini CQ \& Gonçalves WM (2018c) Nutritional evaluation of nonconventional vegetables in Brazil. Anais da Academia Brasileira de Ciências, 90:1775-1787.

Singh A, Singh R \& Singh K (2005) Growth, yield and economics of rice (Oryza sativa) as influenced by level and time of silicon application. Indian Journal of Agronomy, 50:190-193.
Takahashi E, Ma JF \& Miyake Y (1990) The possibility of silicon as an essential element for higher plants. Comments on Agricultural and Food Chemistry, 02:99-102.

Wang M, Wang XD \& Wang JJ (2016) Effect of silicon application on silicon contents in "Fuji" Apple in Loess Plateau. Communications in Soil Science and Plant Analysis, 47:23252333.

Xavier JB, Castro DG, Silva DM, Abreu RAA, Souza DC \& Silva MLS (2019) Eficiência de absorção de nutrientes em Amaranthus spp. Magistra, 30:199-210.

Xu HW, Lu Y \& Xie ZM (2016) Effects of silicon on maize photosynthesis and grain yield in black soils. Emirates Journal of Food and Agriculture, 28:779-785.

Yamaji N \& Ma JF (2007) Spatial distribution and temporal variation of the rice silicon transporter Lsi1. Plant Physiology, 143:1306-1313.

Zanetti LV, Milanez CRD, Gama VN, Aguilar MAG, Souza CAS, Campostrini E, Ferraz TM \& Figueiredo FAMMA (2016) Leaf application of silicon in young cacao plants subjected to water deficit. Pesquisa agropecuária brasileira, 51:215-223. 